International Research Journal of Engineering, IT \& Scientific Research
Available online at https://sloap.org/journals/index.php/irjeis/
Vol. 5 No. 4, July 2019, pages: 55 67
ISSN: 2454-2261
https://doi.org/10.21744/irjeis.v5n4.703

\title{
Leaflet Method for Effectiveness of Health Counseling on Diarrhea Prevention Behavior
}

Indra Rahmad ${ }^{\mathrm{a}}$

Desty Emilyani ${ }^{\text {b }}$

Akhmad Fathoni ${ }^{c}$

\section{Article history:}

Received: 09 March 2019

Accepted: 31 May 2019

Published: 31 July 2019

\section{Keywords:}

health;

counseling;

diarrheal;

disease;

children;

\begin{abstract}
Diarrhea is a dangerous disease in children. It can lead to death and cause an outbreak of extraordinary events. The main cause of death in diarrhea is dehydration, namely as a result of the loss of fluid and electrolyte salt in stool diarrhea. If dehydration is not immediately helped $20-30 \%$ of them could die. In order to analyze the effectiveness of health counseling on diarrheal disease prevention behavior with leaflet method on families who have children aged 0 - 5 years at Raba sub-district, Bima City in 2018. This research used Paired T-test research with One Group Pre-Post Test Design approach to 200 people sample. Sample selection sampling technique used a non-probability sampling type with purposive sampling technique, namely the selection of the entire sample. It is in accordance with the characteristics set by the researcher in the inclusion criteria. The results of the two variables analysis above using the Paired T-test, the t-value $=7.053$ and $\mathrm{p}=0.000$ were obtained. The t-value $=7.053$ indicated that there was strong effectiveness between two variables seen from the interpretation table of the correlation coefficient. The p-value $=0,000$ was smaller than the alpha value of 0.05 . it means Ho was rejected and Ha was accepted. Based on the results of the study, it can be concluded that there is a strong and significant effect between maternal behavior before and after health counseling.
\end{abstract}

2454-2261 ${ }^{\odot}$ Copyright 2019. The Author. This is an open-access article under the CC BY-SA license (https://creativecommons.org/licenses/by-sa/4.0/) All rights reserved.

\section{Author correspondence:}

Indra Rahmad,

Polytechnic of Health, Mataram, Indonesia.

Email address: indrarahmad912@gmail.com

${ }^{\text {a }}$ Polytechnic of Health, Mataram, Indonesia

${ }^{b}$ Polytechnic of Health, Mataram, Indonesia

${ }^{\mathrm{c}}$ Polytechnic of Health, Mataram, Indonesia 


\section{Introduction}

Diarrheal disease problem general is one of the environmental-based diseases. It is still the biggest health problem in Indonesia either due to the poor condition of basic sanitation, physical environment, and low behavior of people to live clean and healthy. There are still many factors causing diarrhea emergence (Depkes RI, 2010). Diarrhea is a dangerous disease in children. It can cause death and cause eruptions of extraordinary events (KLB). The main cause of death in diarrhea is dehydration. It is a result of the loss of fluid and electrolyte salts in the diarrheal stool (Depkes RI, 2010). If dehydration state is not helped immediately $20-30 \%$ of them can die.

Data in 2011 revealed nearly 11 million children died before reaching five years old. More than half, about six million children die from diseases. They are easily prevented or treated. The children die approximately two million from diarrhea. It is actually easily overcome by giving fluids (rehydration). The diarrhea cases incidence usually will also increase from February to April. Wherein, April is still the rainy season, when the diarrhea prevalence due to rotavirus is high. In the following April, the diarrhea incidence decreased. Then, arise again in July, dry season, when there was a lack of clean water met health requirements.

The high mortality and illness in diarrhea cases are due to several factors. It is included inadequate environmental health, nutritional conditions, population, education, socio-economic conditions, and community behavior. It has spurred the government to make the main health program. One of the main health development programs in infectious diseases eradication and immunization in which the target to be achieved is to reduce mortality due to diarrhea in the toddler group from 2.5 to $1 / 1000$ children and prevent the incidence extraordinary (Healthy Indonesia Vision, 2010).

Diarrhea is indeed still common in children. Therefore, the parent's concern about diarrhea is a natural thing. They must be understood. The problem precisely is, if there are parents who are indifferent or less aware of children who have diarrhea. For example, in the community, diarrhea is believed or considered a sign that the child will grow or develop. It can occur due to lack of family knowledge about diarrheal diseases, unlike causes, ways to prevent, and treat them. Unlike beliefs can unconsciously reduce the vigilance of parents. Thus, diarrhea might endanger the child (Depkes RI, 2010).

Data obtained from the Penanae public health at Raba Subdistrict, Bima City, the number of diarrhea incidents among under-five sufferers for the January-December 2011 period of 43 infants was four cases (9.3\%). In JanuaryDecember 2012 period, there was an incidence of 48 children under five totaling six cases $(12.5 \%)$. Whereas, in January-October 2013 period, there was an incidence of 51 children under five in seven cases (13.7\%). Data above shows that there is a tendency to increase diarrhea cases in infants from the previous year.

Various efforts can be conducted in order to prevent diarrheal diseases in Kendo Village, Raba Subdistrict, Bima City are counseling included, for example, promotion of breast milk, improvement of complementary feeding, clean water use, improvement of personal hygiene, and environmental sanitation. Based on the above background, the problem can be formulated towards leaflet method for the effectiveness of health counseling on diarrheal prevention behavior

The impacts of the knowledge and people behavior who do not understand clean and healthy living behavior will have an impact on morbidity and mortality rates, causing a decrease in health status (Dami et al., 2019). The case often occurs every year is a diarrheal disease. The efforts made to reduce diarrhea cases are by counseling. Provided counseling is expected to increase family knowledge about diarrheal diseases. It can affect family behavior in preventing diarrheal disease in children 0 - 5 years. Therefore, the increase in diarrhea every year can be suppressed. The intended family in the study is the mother or father caring for the child.

\section{Literature Review}

Counseling is an effort made to change the behavior of person, group, community. Thus, they have the ability and habit of living behavior in the health sector (Ruano et al., 2019). The purpose of health education is to foster changes. They are directed in activities to improve the degree of health and life. The changes cover the level of knowledge, skills or abilities, attitudes, and motives of individual or community actions.

1) Changes in the level of knowledge, including changes from what they now know. Then, it was less profitable through their health.

2) Changes in the level of proficiency or ability, including changes in the proficiency/ability to think, what initially did not receive enough attention, the act of giving a view of things that are beneficial. 
3) Changes in attitude, including changes in behavior and feelings. They are supported by the existence of skills, abilities, and thoughts.

4) Changes in the motive for action, including changes in what they usually do and actually do, is less favorable for health. Therefore, it becomes more favorable treatments. They are supported by increased confidence and thinking power.

According to Soekidjo (2007), the objectives of health education/counseling are:

1) Achieving changes in the behavior of individuals, families, and communities in fostering and maintaining healthy behavior. The healthy environment plays an active role in efforts to achieve optimal health.

2) The formation of healthy behavior in individuals, families, groups, and communities in accordance with the concept of healthy living, both physically and mentally and socially. Thus, it is as to reduce morbidity and mortality. According to WHO (1999), the purpose of health education is to change the behavior of a person and/or the community in the health sector.

A teaching method causes the recipient to be passive and thinking and the lesson to be active and think. It is based on goals to individual Approach (interview and consultation), group approach (lecture, lecture, discussion, and seminar), and mass approach (film exhibitions and meetings). The interview is one way of health education by holding question and answer and direction towards the goal. The lecture is a way of health education in which we apply to know, explain something verbally, accompanied by questions and answers. The demonstration is a way of presenting an understanding or idea. They have been carefully prepared to show how to carry out a procedure. An exhibition is a collection of materials on a matter regularly and is interesting to show.

The application of communication in counseling is included elements of communication (message sender, order, message recipient, channels, and purpose) and the term of affect communication (look at it from the communicator, communication skills, communication attitude, communication knowledge, social communication system, media, and communication tools).

The family is the smallest unit of society consisting of the head of the family and several people who are gathered and live in a place and a house, a state of interdependence (Ministry of Health, 2006). The family types/forms are nuclear families consisting of a father, mother, and child. The extended family consists of a nuclear family plus cousins, uncles, aunts and so on. Chain family is a family of women and men who have been married more than once and is a nuclear family. Single-family is widows, families occur due to divorce/death. Composition family is family whose marriage is polygamy and live together. Cabity families are people who live in one house without marriage but form one family.

The family function is biological function, forward descendants, caring for and raising children, meet the nutritional needs of the family, and care for family members. The psychological function is to provide affection and security, giving attention among family members, and providing a family identity. The economic function is included looking for sources of income to meet family needs, arrangements for the use of family income to meet family needs and saving money to meet family needs in the future. The education function is included schooling children to provide knowledge, skills, and shape children's behavior in accordance with their talents and mandate, preparing children for adult life to come in fulfilling their role as adults, and educate children according to their development level (Suiraoka et al., 2017).

There are six family tasks included physical maintenance of family and members, maintenance of resources in the family, tasks division for each member in accordance with their respective positions, socialization among family members, placement of family members in the wider community, and generating the encouragement and enthusiasm of family members.

Diarrhea is a disease with signs of changes in shape and consistency from softening of feces to melting and increasing frequency of bowel movements usually three or more times a day. Intestinal inflammation by the causative agent for example bacteria (vibrio cholera, shigella, e-coli and others), viruses (rotavirus, adenovirus, and others), parasites (protozoa, stomach worms, mushrooms), food or beverage poisoning both caused by bacteria and chemicals, malnutrition, which is lack of protein-energy, not resistant to certain foods, for example intolerant of milk lactose, immunodeficiency. The other factors are for example less supply of clean water, lack of personal sanitation and hygiene facilities, and an appropriate complementary feeding, etc. The seasonal and geographical factors of the region. They are included some behaviors can increase the risk of diarrhea in infants.

Rahmad, I., Emilyani, D., \& Fathoni, A. (2019). Leaflet method for effectiveness of health counseling on diarrhea prevention behavior. International Research Journal of Engineering, IT \& Scientific Research, 5(4), 55-67. 
a) Not giving full milk for the first 4-6 months. The toddlers who are not breastfed, the risk of suffering from diarrhea is greater than toddlers who are given full breastfed, and the likelihood of suffering from severe dehydration is greater.

b) Using milk bottles, the use of these bottles facilitates pollution by germs because the bottles are difficult to clean. The use of bottles are not clean or have been used for hours are left in a hot environment, often causing severe intestinal infections. Due to the bottles can be contaminated by germs/bacteria that cause diarrhea. Therefore, the toddlers who use these bottles are at risk of getting diarrhea.

c) Store cooked food at room temperature, if the food is stored for several hours at room temperature. It will be scattered and germs will multiply.

d) Using polluted drinking water.

e) Not washing hands after defecation and defecating a child or before eating and feeding a child.

f) Not disposing of feces properly, often assume feces are harmless, when in fact they contain a large number of viruses or bacteria. Animal feces can also cause infections in humans.

Table 1

The clinical manifestations of dehydration

\begin{tabular}{llll}
\hline & $\begin{array}{l}\text { Isotonic (loss of water and } \\
\text { salt) }\end{array}$ & $\begin{array}{l}\text { Hypotonic (Loss of salt } \\
\text { in excess water) }\end{array}$ & $\begin{array}{l}\text { Hypertonic (loss of water in } \\
\text { excess salt) }\end{array}$ \\
\hline skin & gray & gray & gray \\
color & cold & cold & cold or hot \\
temperature & bad & very bad & is \\
turgo & dry & wet & thick, clay \\
feeling & dry & It's a little damp & dry and hot \\
mucous membrane & there is no & there is no & there is no \\
tears and salivation & concave and soft & concave and soft & sunken \\
eyeball & sunken & sunken & sunken \\
body temperature & below normal or increasing & abnormal & below normal or increasing \\
fontanel & & & \\
pulse & & hurry up & medium speed \\
respiratory & hurry up & lethargy go into a coma & hurry up \\
behavior & hurry up & convulsions & real lethargy with extreme \\
& sensitive to lethargy & & hyperactivity to stimulation \\
\hline
\end{tabular}

The proper treatment and effective diarrhea case management through (a) the efforts to oral dehydration with ORS and household fluids, (b) forwarding the food a little but repeatedly during diarrhea and extra food after diarrhea, (c) breast milk is also continued, (d) intravenous therapy is only for severe dehydration, and (e) medical therapy as indicated for anti-diarrhea is not recommended in patients with toddler diarrhea and antibiotics or anti microbes are only given. If the exact cause is known (a) pathogenic bacteria are found on microscopic examination or culture, (b) blood is found in the stool during the microscopic examination, (c) in endemic areas of cholera (and given tetracycline), and (d) in neonates if the nosocomial infection is suspected.

The preventive action can be conducted for example (a) effective diarrhea prevention efforts, (b) health of both mother and child, (c) nutrition improvement is to promotion of breast milk, improvement of complementary foods (weaning food), (d) use of clean water, and (e) improved personal hygiene and environmental health is to proper disposal of feces, and hand washing. Behavior is seen in terms of biologically is an activity or activity of the organism concerned. Therefore, human behavior is essentially an activity of humans themselves. Behavior and behavioral symptoms appear in the activities of these organisms are influenced by genetic (hereditary) and environmental factors. Heredity is a basic concept or capital for the development of the behavior of living things in the future.

Robert Kwick (1974), stated that behavior is an action or deed of an organism that can be studied. Skinner (1938), suggested that behavior is the result of a relationship between stimulus and response. He distinguished two responses namely, respondent response or reflexive is the response caused by certain stimuli because it gives rise to a relatively fixed response and operant response or instrumental response, responses that arise and develop that are followed by certain stimulation. 
The procedure for behavior formation is the most human behaviors are operant responses. To shape this type of response behavior or behavior, certain conditions called operant conditioning need to be created. It is for the formation of behavior in operant conditioning according to Notoatmodjo (2003), is as follows:

a) Identify things that are reinforcement or reinforcers in the form of prizes or rewards for the behavior to be formed.

b) Conduct analysis to identify the small components that make up the desired behavior.

c) Use in sequence the components as interim goals, identifying reinforcers or prizes for each component.

d) Perform the behavior formation using components sequence have been arranged.

e) As an example, children have brushing habit for their teeth before going to bed.

According to Rogers (1974), before a new person behaves individually, there have been several processes, namely (a) awareness wherein the person realizes in knowing sense object in advance (stimulus), (b) interest wherein people start to be attracted to the stimulus, (c) evaluation weighs whether or not the stimulus for them, (d) a trial wherein people have started trying new behaviors, and (e) adaptation wherein the subject has behaved recently in accordance with knowledge, and their attitude to the stimulus.

The more operationally behavior can be interpreted as an organism or someone's response to stimuli (stimulus) from outside the subject. This response consists of two types: (a) passive form is an internal response that is happening inside of humans and is not directly visible to others, for example thinking, responses or attitudes and knowledge and (b) the active form is if the behavior is clearly observable directly, for example, family behavior prevents the transmission of diarrheal disease in infants. The factors that influence the formation of behavior can be divided into two, namely (a) internal factors include knowledge, intelligence, perception, emotions, motivation and so on, and (b) external factors include the surrounding environment both physical and non-physical such as climate, humans, economy, culture and etc.

The research conceptual framework is a relationship between one concept with other concepts to be investigated (Notoatmodjo, 2003). H1: there is "the effect of health counseling on the prevention of diarrhea behavior using the leaflet method on families with children 0-5 years old in Raba subdistrict, Bima City".

\section{Materials and Methods}

This research was conducted in Raba subdistrict on the working area of the public health center, Bima city from July to September 2018. Nursalam (2003), stated that research design is a strategy to achieve research objectives and acts as a research guide for the entire research process. Referring to existing problems formulation, the research is used cross-sectional based on the case occurred. The research design used was a quasi-post-test only non-equivalent control group experiment. The inter-respondent intervention group is the control group (Dharma, 2011).

The research group was divided into two namely intervention group. The families with children under five who were given counseling and the control group, namely those who had children under five who were not given information on the research design in the following Figure 1.

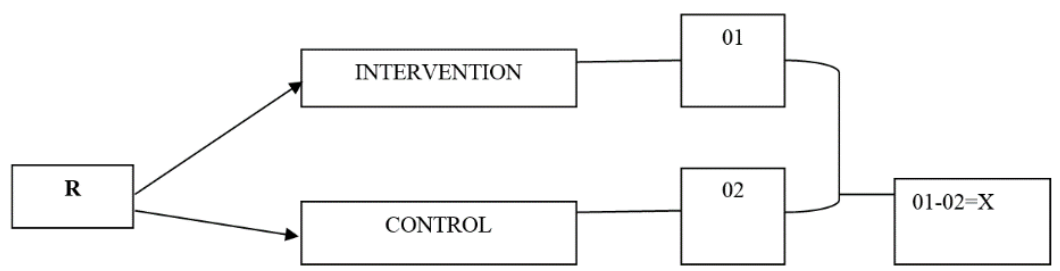

Figure 1. Research Design

\section{Description:}

$\mathrm{R} \quad$ : Research respondents

01 : observation of diarrhea prevention in children 0-5 years old who are given counseling

02 : observation of diarrhea prevention in children 0-5 years old who are not provided counseling

Rahmad, I., Emilyani, D., \& Fathoni, A. (2019). Leaflet method for effectiveness of health counseling on diarrhea prevention behavior. International Research Journal of Engineering, IT \& Scientific Research, 5(4), 55-67. 
01-02 : comparison of diarrhea prevention in children 0-5 years in the intervention group and the control group

Variables are characteristics have owned the subjects (people, objects, situations). They are different from those owned the group (Nursalam 2003). Independent variable is the variable that is the cause of the occurrence or change of the dependent variable. The independent variable in this study is family counseling about diarrhea. It is included understanding, etiology, signs, symptoms, and prevention which are categorized: good, sufficient, and less. The dependent variable is a variable that is affected or that is due to the presence of independent variables. The dependent variable in this study is the behavior of diarrheal disease prevention in children 0 - 5 years old with categories: good, sufficient, and less. The population is the whole object that meets the established criteria (Nursalam, 2003). The population in this study were all families who have children 0-5 years old at Raba subdistrict, Bima City in the period from June to August 2018, about 400 people.

The sample consists of parts that can be used as research subjects through sampling (Nursalam, 2003). The criteria for getting a sample are two kinds namely inclusion criteria and exclusion criteria. Inclusion criteria are the general characteristics of research subjects from an affordable target population to be studied. Exclusion criteria are excluding subjects who meet the inclusion criteria from the study for various reasons (Nursalam, 2003). The criteria are included (a) families who have children 0-5 years old, (b) families who are willing to be respondents, (c) families who live in Kendo Village, and (d) family that can read. The sample size of the population according to Riduwan (2005) is as follows:

$$
\mathrm{n}=\frac{\mathrm{N}}{1+(\mathrm{d})^{2}}
$$

Description:

$\mathrm{n}$ : estimated sample size

$\mathrm{N}$ : estimated population size

d : selected error rate $(d=0,05)$

$$
\begin{aligned}
& \mathrm{n}=\frac{1920}{1+1920(0,050)^{2}} \\
& \mathrm{n}=\frac{1920}{9,6}=200
\end{aligned}
$$

Therefore, the sample size is 200 respondents. According to Nursalam (2003), sampling is the process of selecting portions of the population to be able to represent the population. This research used a proportionate stratified random sampling method. It is a technique used if the population has members/elements. They are not homogeneous and proportionally distributed.

Data collection was conducted after obtaining permission from the Head of Kendo Village, Raba subdistrict, Bima City. Wherein, the researcher formally submitted a written request from the educational institution to conduct the research. Furthermore, new researchers are gathering data. The research data will be collected. (a) General data is research data that will not be further analyzed and discussed, including (age, occupation, education, and place to obtain health information). (b) Specific data is research data that will be tested for further analysis and discussion. It includes data on knowledge and behavior. The research data are then collected using a questionnaire to be filled out.

The collected data is tabulated and grouped according to the sub-variables studied based on the research objectives. Editing is conducted to find out whether the data obtained is filled in correctly according to the charging instructions. Coding is to classify the answers obtained according to their kind by coding each answer according to items on the questionnaire with B (good), C (enough), $\mathrm{K}$ (less) and the last is tabulating. Tabulating is a data processing activity. Therefore, it can easily be added up and arranged to be presented and analyzed.

The initial activity undertaken is to re-check the completeness of the answers that have been filled to the subject on the questionnaire distributed. Then, each answer is evaluated in numbers to facilitate management. The grouped data is coded on each answer according to the items in the questionnaire with B (good), C (enough), K (less). It is to facilitate researchers in recapitulating data in a computer. Therefore, the data is processed according to the type and scale of measurement in accordance with statistical analysis needs. 
The analysis technique used is descriptive and inferential statistical techniques. Descriptive statistics are used to present data and variables both singly and together. The analysis is conducted at presenting a frequency distribution to calculate the percentage of each answer to a research question. This analysis technique is in the form of an inferential test or significance test using spearman rho correlation with a significance level of 0.05 and a p-value. This testing technique looks at the relationship between two dependent and independent variables using a computer.

The researcher in conducting the research has submitted an application for permission to the Head of Kendo Village, Raba subdistrict, Bima City. Data collection activities could be done by taking into account ethical issues. They are included (a) respondents were given an explanation of the aims and objectives during data collection. If the respondent is willing to be investigated. They must sign the consent form to become the respondent. Prospective respondents who are unwilling will not be forced and remain respected. (b) The confidentiality of research respondents was made a priority, not including names in the research questionnaire but only using code numbers. The confidentiality of information provided by respondents in research will be guaranteed by researchers.

\section{Results and Discussions}

\subsection{Results}

The research location has an area of $6,373 \mathrm{~km}^{2}$ (11 Villages) about 40,306 people. There are 20,540 men and 19,766 women. They are also northern boundaries: asakota, south: east rasanae, west: mpunda sub-district, east: east rasanae sub-district. There are 400 children 0-5 years old in Bima City.

The activities are routine farmer group meetings, social gathering of mothers, recitation once a month, activities related to health services including posyandu are held once a month. Health education is only done when certain events such as dengue fever occur and bird flu. Therefore, it is only at the time of the incident the health worker jumped into the field to provide counseling about dengue fever and bird flu. As for health education about diarrhea, it has been done but only once. Therefore, the awareness to prevent diarrhea is still low. Based on the results of data collection that have been done, it is obtained characteristics of respondents include:

a) Characteristics of respondents based on maternal age

Table 2

The frequency distribution of characteristics of respondents based on maternal age

\begin{tabular}{lll}
\hline Age & Frequency $(\mathrm{f})$ & Percentage $(\%)$ \\
\hline $15-20$ years old & 23 & 11,5 \\
$21-35$ years old & 140 & 70 \\
$36-45$ years old & 36 & 18 \\
$>45$ years old & 1 & 0,5 \\
Total & 200 & 100 \\
\hline
\end{tabular}

Source: Primary data, 2018

Table 2 shows that the respondents of characteristics of respondents based on maternal 21-35 years old. It is 140 people or equivalent to $70 \%$. The least respondent is mothers who are $>45$ years old with a percentage of $0.5 \%$ or only 1 respondent.

b) Characteristics of respondents based on the education level

The level of education of respondents is limited by taking respondents who have a minimum level of education on the elementary and maximum degree. The respondent's characteristics based on education level.

Rahmad, I., Emilyani, D., \& Fathoni, A. (2019). Leaflet method for effectiveness of health counseling on diarrhea prevention behavior. International Research Journal of Engineering, IT \& Scientific Research, 5(4), 55-67. https://doi.org/10.21744/irjeis.v5n4.703 
Table 3

The frequency distribution of research respondent characteristics based mother's education level

\begin{tabular}{lll}
\hline Education Level & Frequency (f) & Percentage (\%) \\
\hline Primary school & 23 & 11,5 \\
Junior high school & 32 & 16 \\
Senior high school & 117 & 58,5 \\
College & 28 & 14 \\
Total & 200 & 100 \\
\hline
\end{tabular}

Source: Primary data, 2018

Table 3 shows that the highest level of maternal education is 117 people or $58.5 \%$ on high school education level. The smallest percentage is $11.5 \%$ on 23 people with primary education level.

c) Characteristics of respondents based on mother's occupation

Table 4

The frequency distribution of research respondent characteristics based mother's occupation

\begin{tabular}{lll}
\hline Profession & Frequency (f) & Percentage $(\%)$ \\
\hline Civil servants & 5 & 2,5 \\
entrepreneur & 15 & 7,5 \\
Housewife & 172 & 86 \\
Farmers & 8 & 4 \\
Total & 200 & 100 \\
\hline
\end{tabular}

Source: Primary data, 2018

Table 4 shows that most types of maternal occupation are housewife 172 people or $86 \%$. The percentage of civil servants is five people or $2.5 \%$.

d) Characteristics of respondents based on health information sources

Table 5

The frequency distribution of research respondent characteristics based on maternal health information sources

\begin{tabular}{lll}
\hline Health Information Sources & Frequency (f) & Percentage (\%) \\
\hline Public health center & 188 & 94 \\
TV/radio & 4 & 2 \\
Newspapers/magazines & 2 & 1 \\
Communities/organizations & 6 & 3 \\
Total & 200 & 100 \\
\hline
\end{tabular}

Source: Primary data, 2018

Table 5 shows that most health information source is 188 people or $94 \%$. The smallest percentage is newspaper/magazine on 2 people or $1 \%$.

e) Maternal Behavior Before Health Counseling

Table 6

The frequency distribution of research respondent characteristics based on maternal behavior prior to health counseling

\begin{tabular}{lll}
\hline Mother's behavior & Frequency (f) & Percentage (\%) \\
\hline Good (16-20) & 156 & 78
\end{tabular}




\begin{tabular}{lll}
\hline Enough (10-15) & 44 & 22 \\
Less (0-9) & 0 & 0 \\
Total & 200 & 100 \\
\hline
\end{tabular}

SPSS test results show in Table 6. It can be seen that the most maternal behavior prior to health education is 156 people or $78 \%$. The mother's behavior in enough category was 44 people or $22 \%$.

f) Maternal behavior after health counseling

Table 7

The frequency distribution of research respondent characteristics based on maternal behavior after health

\begin{tabular}{lll}
\hline Mother's behavior & Frequency (f) & Percentage $(\%)$ \\
\hline Good (16-20) & 196 & 98 \\
Enough (10-15) & 4 & 2 \\
Less (0-9) & 0 & 0 \\
Total & 200 & 100 \\
\hline
\end{tabular}

SPSS test results show in Table 7. It can be seen that the most mother's behavior after health education is 196 people or $98 \%$.

g) Cross tabulation between mother's behavior before and after health education

Table 8

The dependent and independent variables

\begin{tabular}{|c|c|c|c|c|c|c|c|c|c|c|c|}
\hline \multicolumn{5}{|c|}{$\begin{array}{l}\text { Mother's behavior before } \\
\text { counseling }\end{array}$} & \multicolumn{6}{|c|}{$\begin{array}{l}\text { Mother' behavior after } \\
\text { counseling }\end{array}$} & \multirow[t]{2}{*}{ T-Test } \\
\hline Good & \multicolumn{2}{|c|}{ Enough } & \multicolumn{2}{|c|}{ Less } & \multicolumn{2}{|c|}{ Good } & \multicolumn{2}{|c|}{ Enough } & \multicolumn{2}{|c|}{ Less } & \\
\hline$\%$ & $\mathrm{~F}$ & $\%$ & $\mathrm{~F}$ & $\%$ & $\mathrm{~F}$ & $\%$ & $\mathrm{~F}$ & $\%$ & $\mathrm{~F}$ & $\%$ & \multirow[t]{2}{*}{$\mathrm{P} \leq 0,000$} \\
\hline 15678 & 44 & 22 & 0 & 0 & 196 & 98 & 4 & 2 & 0 & 0 & \\
\hline
\end{tabular}

The analysis of the two variables above using Paired T-Test, t-value $=7.053$ and $\mathrm{p}$-value $=0.000$ was obtained. $\mathrm{T}$-value $=7.053$ indicates that there is strong effectiveness between the two variables seen from interpretation table of the correlation coefficient according to (Sugiyono, 2014). P-value $=0,000$ is smaller than the alpha value of 0.05. it means that Ho is rejected and $\mathrm{Ha}$ is accepted. Therefore, it can be concluded that there is a strong and significant effect on maternal behavior before and after health education.

\subsection{Discussion}

a) Diarrhea prevention behavior in mothers who have children 0-5 years old before counseling using leaflet method

The results were obtained that before counseling about diarrhea prevention behavior among mothers who have children 0-5 years old, based on the results of the questionnaire answers, the highest score was 20 , the lowest score was 13, before counseling. It was known that diarrhea prevention behavior scores for mothers with children 0-5 years old with good category about 156 people or $78 \%$. Enough behavior of about 44 people or $22 \%$. The category of less than 0 people or $0 \%$. The results showed that most diarrhea prevention behaviors in mothers who had children 0-5 years old before counseling with good category. Diarrhea prevention behavior can be influenced by a person's knowledge.

Rahmad, I., Emilyani, D., \& Fathoni, A. (2019). Leaflet method for effectiveness of health counseling on diarrhea prevention behavior. International Research Journal of Engineering, IT \& Scientific Research, 5(4), 55-67. https://doi.org/10.21744/irjeis.v5n4.703 
b) Diarrhea prevention behavior for mothers who have children 0-5 years old after counseling using leaflet method

The results showed that after counseling about diarrhea prevention behavior in mothers who have children 0-5 years old, based on the results of the questionnaire answers, the highest score is 20, the lowest score is 14 , after counseling. It is known that diarrhea prevention behavior scores for mothers who have children $0-5$ years old with good category about 196 people or $98 \%$. Enough behavior is for four people or $2 \%$. The less category than 0 people or $0 \%$. The results showed that most diarrhea prevention behaviors in mothers who had children $0-5$ years old before counseling with good category. Individual behavior is closely related to health problems. It is basically the current response to stimuli related to illness, health services, food, and the environment. Therefore, someone is motivated to conduct diarrhea prevention behavior and maintain their health with preventive measures in children $0-5$ years old.

c) Effectiveness of health counseling using leaflet method on diarrhea prevention behavior in mothers of children 05 years old in Raba subdistrict, Bima City

The diarrhea prevention behavior in mothers who have children 0-5 years old before and after counseling has (p>0.05). Thus, the data is normal. From the results of the analysis with t-test, a significance value of $0.000(p$ $<0.05)$ was obtained, the $t$-count was 7.053 with a $t_{\text {table }}$ value for $(p<0.05)$; is 3,390 . It is known that $t_{\text {count }}>t_{\text {table }}$. Therefore, it can be stated there is an effect of health education about diarrhea on diarrhea prevention behavior in mothers of children 0-5 years old in Raba subdistrict, Bima City.

The mother's participation in counseling related to diarrhea prevention in children $0-5$ years old can increase knowledge and diarrhea prevention and understand the negative effects of diarrhea on infants and children. It is inhibiting the process of growth and development of children. It can ultimately reduce the quality of children life. According to Hidayat (2008), the diarrheal disease in the community (Indonesia) better known as "muntaber". The disease has a terrible connotation and causes anxiety and panic among citizens because if it is not treated immediately within a short time ( \pm 48 hours) the patient will die.

Nutritional factors can affect the incidence of diarrhea, for example, not given additional food even, if the child is 4-6 months old or lack of food intake. Children who do not develop well are often affected by diarrhea if they are affected diarrhea eating conditions will be more severe compared to children who have good nutrition. Therefore, children's nutrition maintenance must also include efforts to prevent infectious diseases such as diarrhea in infants.

The main educational factor is the mother's knowledge about health problems and diarrhea prevention behavior. The highest level of mother's education is the level of senior high school education of 54 people or $54 \%$. The smallest percentage of $12 \%$ is mothers with an elementary education level of 12 people. Knowledge about one's health is a very important role in determining the health value. The variety of health information will broaden their knowledge and understanding of health and disease prevention.

Diarrhea prevention behavior is preventive. Therefore, it can reduce the incidence of diarrhea. The results of the study show that counseling has an important role to increase knowledge and behavior of diarrhea prevention appropriately in infants. Due to there are still many mothers who pay less attention to behavior. It can cause diarrhea in addition, many people do not know how to prevent diarrhea, with the provision of health education by the health department through puskesmas and posyandu and health cadres need to be promoted in a sustainable manner. Thus, the incidence of diarrhea in children 0-5 years old is a reduced level of knowledge of the good one.

Diarrhea prevention behavior can be influenced by the level of knowledge obtained from health education with good knowledge about diarrhea, of course, diarrhea prevention behavior will be better (Notoatmodjo, 2003). The results are in accordance with Laila (2006), with the title of the relationship between maternal knowledge about the use of clean water and prevention of diarrhea in toddlers in the Bima City, Notoprajan Yogyakarta. The analysis results are in accordance with the hypothesis in this study. There is an effect of health education on diarrhea prevention behavior for mothers who have children 0-5 years old.

Counseling using leaflets is an effort to improve and change the knowledge, attitudes, and practices of diarrhea prevention behaviors for mothers towards better prevention. Factors that support research include facilities, the role of extension workers, the media in counseling, the material delivered, the means that show is given. The quality of audience mastery therefore in providing information to respondents can be effective health education should use a two-way method. Thus, it is expected that the level of understanding of the message 
conveyed will be clearer and easier to understand. It will not be miscommunication. The parents who were given counseling turned out to be able to increase knowledge to change the behavior of diarrhea prevention in children 0-5 years old. This is in harmony with Syarifudin (2009), stated that health education is directed can change one's knowledge and behavior in a better direction.

\section{Conclusion}

It can be concluded the diarrhea prevention behavior of mothers who have children 0-5 years old in Raba subdistrict, Bima City are:

1) Before counseling, it is known that many respondents did not prevent diarrhea unlike never using clean water on their own, rarely taught children to wash their hands before and after eating, and never wash bottles where they drink milk every day. Most respondents answered the score in the good category (80\%).

2) After counseling is known to have experienced changes, which is already using its own clean water, teaching children to wash their hands before and after eating, and often washing bottles were to drink every day. Most respondents answered the score with a good category (98\%).

3) There is an effect of health education on diarrhea prevention behavior among mothers who have children 0-5 years old in Bima City in 2018. It is proven of the analysis results by t-test $\left(\mathrm{t}_{\text {count }}=4,662, \mathrm{P}=0,000\right)$.

\section{Suggestions}

The relevant suggestions can be given are as follows:

1) Nurse

In order to improve and optimize health education, especially, about diarrhea prevention behavior among mothers who have children 0-5 years old. The health education using the leaflet method has an effective effect on awareness of diarrhea prevention behavior in mothers.

2) Mothers and community

In order to be able to participate in various counseling conducted both by cadres or by midwives at the public health to get correct information about diarrhea prevention behavior. Thus, they can take preventive action.

3) Next researcher

It is hoped that research can continue to be better replacing other variables related to toddler health. Therefore, it can improve the function of counseling and provide information to the public at large relating to toddler health.

\section{Conflict of interest statement}

The authors declared that they have no competing interest.

\section{Statement of authorship}

The authors have a responsibility for the conception and design of the study. The authors have approved the final article.

\section{Acknowledgments}

The authors would like to thank the editor of IRJEIS for their valuable time, support, and advice in completing the current research.

Rahmad, I., Emilyani, D., \& Fathoni, A. (2019). Leaflet method for effectiveness of health counseling on diarrhea prevention behavior. International Research Journal of Engineering, IT \& Scientific Research, 5(4), 55-67. 


\section{References}

Dami, Z. A., Pandu, I., Anakotta, E., \& Sahureka, A. (2019). The contribution of levinas' conception of responsibility to the ethical encounter counselor-counselee. International Journal of Social Sciences and Humanities, 3(2), 71-83. https://doi.org/10.29332/ijssh.v3n2.291

Definition, W. H. O. (1999). diagnosis and classification of diabetes mellitus and its complications: report of a WHO consultation.

Depkes RI (2010). Cara Fasilitasi Masyarakat Tentang Perubahan Perilaku Buang Air Besar di Tempat Terbuka, Jakarta.

Depkes RI (2010). Indikator Indonesia Sehat 2010 dan Pedoman Penetapan Indikator Propinsi Sehat dan Kabupaten Sehat/Kota Sehat

Depkes RI (2010). Pedoman Pemberantasan Penyakit Diare, Edisi Ke-3 Jakarta.

Depkes RI (2010). Perbaikan Dan Pengawasan Kualitas Air Dan Lingkungan Untuk Mendukung Pendekatan.

Depkes RI (2010). Rencana Pembangunan Kesehatan Menuju Indonesia Sehat 2010, Jakarta.

Dharma, K. K. (2011). Metodologi penelitian keperawatan. Jakarta: Trans Info Media.

Hidayat, D., Ogi, T., Iskandar, F., \& Okuyama, K. (2008). Single crystal ZnO: Al nanoparticles directly synthesized using low-pressure spray pyrolysis. Materials Science and Engineering: B, 151(3), 231-237.

Indonesia, K. K. R., \& Kesehatan, P. P. (2006). Pedoman Pelaksanaan Pengembangan Desa Siaga. Dalam: Kementerian Kesehatan Republik Indonesia, editor. Jakarta.

Kwick, R. (1974). dalam Notoatmodjo, Soekidjo. 2003. Pendidikan Dan Perilaku Kesehatan.

Laila, D. S., Nešić, D., \& Astolfi, A. (2006). 3 sampled-data control of nonlinear systems. In Advanced topics in control systems theory (pp. 91-137). Springer, London.

Menteri Kesehatan, R. I. (2006). Keputusan Menteri Kesehatan Rupublik Indonesia Nomor 424. MENKES/SK/VI/2006 Tentang Pendoman Pengendalian Cacingan. Kementrian Kesehatan Republik Indonesia. Jakarta.

Notoatmodjo, S. (2003). Pendidikan dan Perilaku Kesehatan. Jakarta: PT Rineka Cipta (2005). Metodologi Penelitian Kesehatan.

Nursalam, S. P., \& Sri, U. (2011). Konsep dan penerapan metodologi penelitian ilmu keperawatan: pedoman skripsi(Doctoral dissertation, Tesis, dan Instrumen Penelitian Keperawatan. Jakarta: Penerbit Salemba Medika).

Riduwan, M. B. A. (2005). Belajar Mudah Penelitian. Bandung, Perpustakaan Nasional RI: Katalog Dalam Penerbitan (KDT).

Rogers, T. B. (1974). An analysis of two central stages underlying responding to personality items: The self-referent decision and response selection. Journal of Research in Personality, 8(2), 128-138. https://doi.org/10.1016/00926566(74)90014-2

Ruano, S. A. H., Estevez, A. G., \& Rodriguez, D. L. (2019). Relationship between behavioral intention and alcohol consumption. International Journal of Health Sciences, 3(2), 21-27. https://doi.org/10.29332/ijhs.v3n2.289

Skinner, H. W. B. (1938). The soft x-ray spectroscopy of the solid state. Reports on progress in physics, 5(1), 257.

Soekidjo, N. (2007). Promosi kesehatan dan ilmu perilaku. PT Rineka Cipta. Jakarta.

Sugiyono, A., Anindita, M. S., \& Boedoyo, A. (2014). Indonesia energy outlook 2014. In Agency for The Assesment and Application of Technology (BPPT).

Suiraoka, I. P., Duarsa, D. P. P., Wirawan, I. D. N., \& Bakta, I. M. (2017). Perception of parents, teachers, and nutritionist on childhood obesity and barriers to healthy behavior: a phenomenological study. International Journal of Health Sciences, 1(2), 1-11. https://doi.org/10.21744/ijhs.v1i2.25

Syarifudin, H. (2009). Kebidanan komunitas. Jakarta: Buku Kedokteran EGC. 


\section{Biography of Authors}

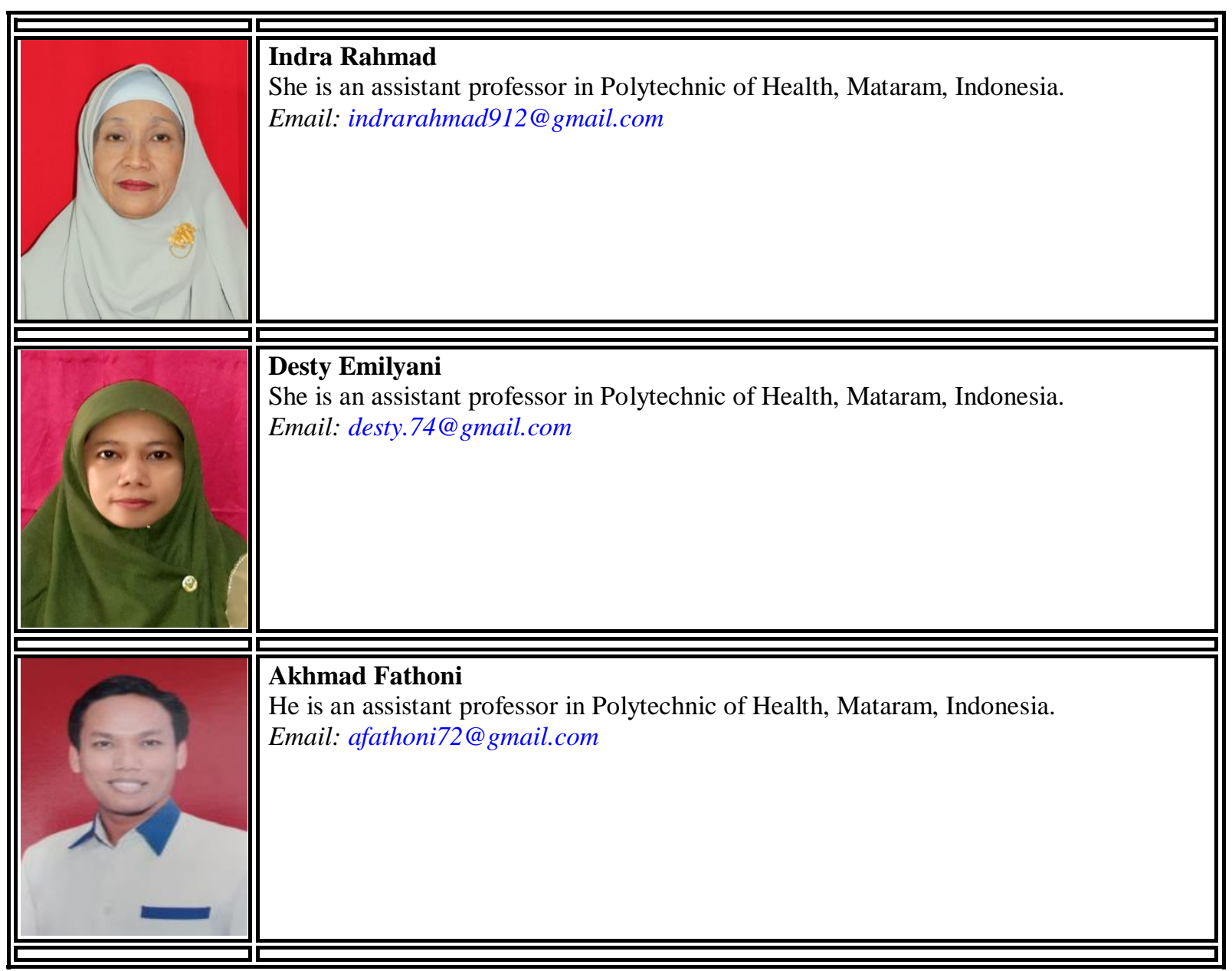

Rahmad, I., Emilyani, D., \& Fathoni, A. (2019). Leaflet method for effectiveness of health counseling on diarrhea prevention behavior. International Research Journal of Engineering, IT \& Scientific Research, 5(4), 55-67. https://doi.org/10.21744/irjeis.v5n4.703 